\title{
空気吸込式イオンエンジンのエアインテーク特性*1 Air Intake Performance of Air Breathing Ion Engines
}

\author{
藤 田 和 央 ${ }^{2}$ \\ Kazuhisa FuJITA
}

Key Words : Rarefied Gas Flows, Air Breathing, Ion Engine, Direct Simulation

\begin{abstract}
The air breathing ion engine (ABIE) is a new type of electric propulsion system which can be used to compensate the aerodynamic drag of the satellite orbiting at extremely low altitudes. In this propulsion system, the low-density atmosphere surrounding the satellite is taken in and used as the propellant of ion engines to reduce the propellant mass for a long operation lifetime. Since feasibility and performance of the ABIE are subject to the compression ratio and the air intake efficiency, a numerical analysis has been conducted by means of the direct-simulation Monte-Carlo method to clarify the characteristics of the air-intake performance in highly rarefied flows. Influences of the flight altitude, the aspect-ratio of the air intake duct, the angle of attack, and the wall conditions are investigated.
\end{abstract}

記 号の説 明

$$
\begin{aligned}
& C_{\mathrm{D}}: \text { 衛星の抗力係数 } \\
& e: \text { 素電荷 }[\mathrm{C}] \\
& G: \text { 圧縮比 }\left(\equiv \rho_{\mathrm{c}} / \rho\right) \\
& G_{0}: \text { 第 } 2 \text { 表に与えられる基準圧縮比 } \\
& h: \text { 気流の比エンタルピ }[\mathrm{J} / \mathrm{kg}] \\
& I: \text { イオンエンジンのビーム電流 }[\mathrm{A}] \\
& i: \text { イオンエンジンのビーム電流密度 }\left[\mathrm{A} / \mathrm{m}^{2}\right] \\
& L_{1}: \text { エアインテークダクト長さ }[\mathrm{m}] \\
& L_{2}: \text { 衛星コアと粒子反射板の距離 }[\mathrm{m}] \\
& m: \text { 排気気流中の分子の平均質量 }[\mathrm{kg}] \\
& \dot{m}: \text { イオンエンジンの排気質量流量 }[\mathrm{kg} / \mathrm{s}] \\
& P_{\mathrm{A}}: \text { イオンエンジンの加速電力 }[\mathrm{W}] \\
& p_{\mathrm{A}} \text { : 単位断面積当たり必要な加速電力 }\left[\mathrm{W} / \mathrm{m}^{2}\right] \\
& P_{\mathrm{s}} \text { : 太陽光放射エネルギー密度 , } 1,370\left[\mathrm{~W} / \mathrm{m}^{2}\right] \\
& R_{1}: \text { 衛星コア半径 }[\mathrm{m}] \\
& R_{2}: \text { 衛星外径 }[\mathrm{m}] \\
& R_{3} \text { : 衛星背面板 (base plate) 半径 [m] } \\
& T_{\mathrm{W}}: \text { 壁面温度 }[\mathrm{K}] \\
& V_{\mathrm{A}}: \text { イオンエンジンの加速電圧 }[\mathrm{V}] \\
& v: \text { 衛星の対大気飛行速度 }[\mathrm{m} / \mathrm{s}] \\
& v_{\mathrm{E}}: \text { イオンエンジンの排気速度 }[\mathrm{m} / \mathrm{s}] \\
& \alpha \text { : 衛星断面積に対する空気取込口断面積の比 } \\
& \beta \text { : 衛星断面積に対する背面板面積の比 } \\
& \chi: \text { エアインテークダクトの縦横比 } \\
& \epsilon_{\mathrm{i}}, \epsilon_{\mathrm{o}} \text { : 壁面内側, 壁面外側の放射率 } \\
& \gamma: \text { 壁面の熱適合係数 } \\
& \eta_{\mathrm{i}}: \text { インテークの空気取込効率 } \\
& \text { *1 (C) } 2004 \text { 日本航空宇宙学会 } \\
& \text { 平成 } 16 \text { 年 } 4 \text { 月 } 6 \text { 日原稿受理 } \\
& \text { *2 宇宙航空研究開発機構総合技術研究本部 }
\end{aligned}
$$

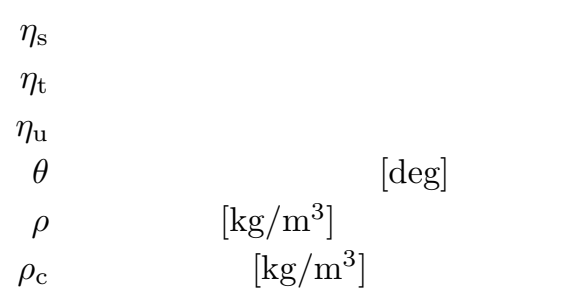

1. 緒言

空気取込式イオンエンジン (air-breathing ion engine ; ABIE) は,西山により提唱されている新しい概念にもとづ くイオンエンジンシステムである ${ }^{1,2)}$. 電気推進器の中でも 高比推力を実現できるイオンエンジンは, 近年, 衛星の姿 勢制御や惑星間軌道遷移など長期的ミッションに利用され るようになって来ており，国内では 2003 年 5 月に打ち上 げられた小惑星探査機 HAYABUSA の惑星間軌道におけ る主推進器としても採用されている3. ESA では, 2006 年 の打上げを目指して重力場と海洋観測のための低軌道衛星 (gravity field and ocean circulation explorer ; GOCE) を開発しており，关の運用軌道高度 $240 \sim 270 \mathrm{~km}$ での大 気抗力補償用推進器としてイオンエンジンを用いることが 検討されている ${ }^{4)}$. 大気抗力補償運用を行う場合, 推進器 の連続運転が必要となることから衛星に占める推進剂重量 の割合か増加し，これが衛星運用の制約条件の一つとなる。 西山の提案する ABIE は , この問題を解決するために衛星 周囲の希薄大気を取り込み，これを推進剂として利用する ことで, 推進剂重量の大幅な低減, 運用可能な軌道高度下 限の拡大，および運用の長期化を図ろうというものである .

第 1 図は西山の発想をベースに，これまでの空気力学的 な検討結果 ${ }^{5,6)}$ を反映させて作成した ABIE 搭載低軌道衛 星の概念図である.空気力学的な抗力をできる限り低減す るために, 飛行方向に垂直な面への衛星の断面積が最小と 


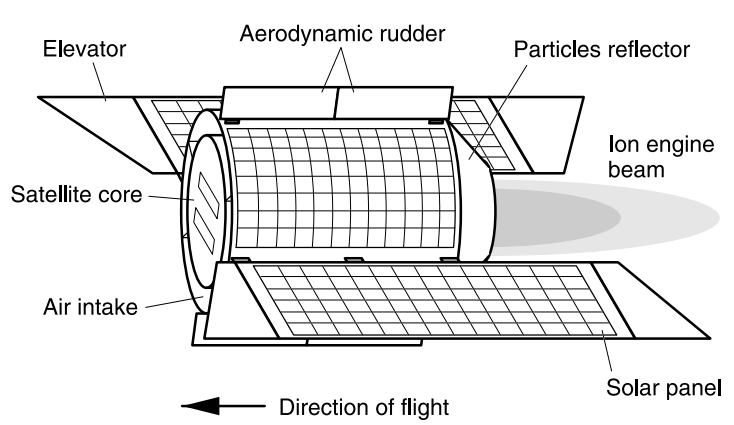

第 1 図 $\mathrm{ABIE}$ 搭載極低軌道衛星の概念図

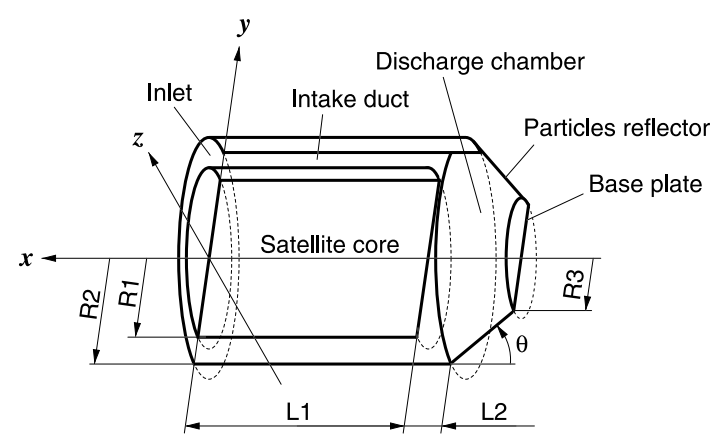

第 2 図 ABIE の幾何モデル (対称面における断面図)

なるように各コンポーネントが配置されている. 空気取込 性能を最大とするためには, 流入粒子の壁面による散乱を できるだけ抑える必要がある.このため衛星コア (satellite core）を円柱状とし，同心円筒シェルでこれを囲んで空気 取込口 (air intake) およびダクトを形成している.取り込 まれた空気は衛星後方の粒子反射板 (particles reflector) で放電室方向へ導入され，電離・加速される．

極低軌道衛星への応用が有望な ABIE であるが, 従来の 推進阂携帯型システムと比較して，どのような運用条件で どの程度メリットが発生するのか, どの軌道高度で実現す るのかなど，未だ明確でない部分が多い，光の理由の一つ が, ABIE の性能に大きな影響を与えると予想される空気 取込過程が不明な点である. 光こで本稿では ABIE の空 気力学的な要素について定量的な検討を行い, システム解 析を行うために必要となる空力的制約条件を明らかにする． 以下の本文では, まず最初に基礎的な条件式を導出し, 続 いてモンテカルロ直接法 (DSMC) によるインテークの解 析を行って空気取込性能を評価し，最後に得られた関係式 を用いてシステムの成立性を検討する .

\section{2. 空気吸込式イオンエンジンの成立条件}

2.1 空気吸込式イオンエンジンの幾何モデル これま での検討を踏まえ，ABIE の空気力学的な特性を定量的に 議論するために，第 2 図に示す幾何モデルを用いる. ABIE の形状を決定するのは $R_{1}, R_{2}, R_{3}, L_{1}, L_{2}, \theta$ の 6 パラメー タである. 衛星コアは半径 $R_{1}$, 長さ $L_{1}$ の円柱とし , イン テークを形成する外筒は半径 $R_{2}$, 長さ $L_{1}+L_{2}$ の円筒とす る. 外筒後方には収束角 $\theta\left(<90^{\circ}\right)$ の円錐台形状の粒子反
射板か設けられており，半径 $R_{3}$ の背面板 (base plate) に 接続している . イオンエンジンのスクリーングリッド半径 の最大值は $R_{3}$ となるが, スクリーングリッド半径が $R_{3}$ よ りも小さくできる場合は，必ずしも背面板全体がスクリー ングリッドである必要はない .

次に無次元形状パラメータとして，インテークダクトの 縱横比, $y-z$ 平面における衛星断面積に対する空気取込口 断面積および背面板面積の割合を，弚れ枈れ

$$
\begin{aligned}
\chi & \equiv L_{1} /\left(R_{2}-R_{1}\right) \\
\alpha & \equiv 1-R_{1}^{2} / R_{2}^{2}=1-\left(1+L_{1} / \chi R_{1}\right)^{-2} \\
\beta & \equiv R_{3}^{2} / R_{2}^{2}
\end{aligned}
$$

と定義する $. R_{3}<R_{1}$ である必要があることから,$\alpha+\beta<1$ である.以下，第 2 図に示す ABIE 形状を用いて議論する.

2.2 抗力補償条件 衛星軌道上で大気抗力補償運用を 行うためには, 大気抗力と推力が平衡する必要がある：

$$
(1 / 2) \rho v^{2} C_{\mathrm{D}} \pi R_{2}^{2}=\dot{m} v_{\mathrm{E}}
$$

イオンエンジンの排気質量流量は

$$
\dot{m}=\rho v \alpha \eta_{\mathrm{i}} \eta_{\mathrm{u}} \pi R_{2}^{2}
$$

と与えられるので，これと式 (4)より排気速度は

$$
v_{\mathrm{E}}=v C_{\mathrm{D}} / 2 \alpha \eta_{\mathrm{i}} \eta_{\mathrm{u}}
$$

となる . イオンエンジンにおいてイオンの加速か理想的に 行われると仮定すると，イオンエンジンのビーム電流，加 速電圧，および加速電力は光れ光れ

$$
\begin{aligned}
& I=\dot{m} e / m=\rho v \alpha \eta_{\mathrm{i}} \eta_{\mathrm{u}} e \pi R_{2}^{2} / m \\
& V_{\mathrm{A}}=m v_{\mathrm{E}}^{2} / 2 e=(m / 8 e)\left(v C_{\mathrm{D}} / \alpha \eta_{\mathrm{i}} \eta_{\mathrm{u}}\right)^{2} \\
& P_{\mathrm{A}}=\dot{m} v_{\mathrm{E}}^{2} / 2=\rho v^{3} C_{\mathrm{D}}^{2} \pi R_{2}^{2} / 8 \alpha \eta_{\mathrm{i}} \eta_{\mathrm{u}}
\end{aligned}
$$

で与えられる．

2.3 熱的条件 ABIE 搭載衛星では通常の太陽放射に 関する熱制約条件と別に，空力加熱による制約と，取込空気 の熱適合に関する制約が存在する.ABIE では雾囲気高速 気流をインテークにより取り込み，粒子反射板で放電室内 方向へ散乱させることで放電室内部の密度上昇を行う、気 流は自由分子流であるため壁面衝突の際に効率良く壁面と 熱適合を行うが，この際に壁面を加熱し，壁面温度が高い 場合は散乱される粒子の熱速度が大きくなり，拡散により 空気取込口から失われる粒子か増加して放電室内の密度が 低下するからである. 壁面条件の空気取込性能に与える詳 細な議論は次節で行うとして，ここでは壁面温度に関する 評価を行う .

一般的な議論を行うために, 第 3 図に示す半径 $R$, 収束 角 $\theta$, 長さ $d L$ の円錐台面要素を考える.これは ABIE の 粒子反射板を摸擬したものであるが， $\theta \rightarrow 0$ の極限では ダクト側壁に，また $\theta \rightarrow 90^{\circ}$ の極限で衛星コアの正面部 に相当する . ABIE は太陽同期軌道をとると考えられるた 


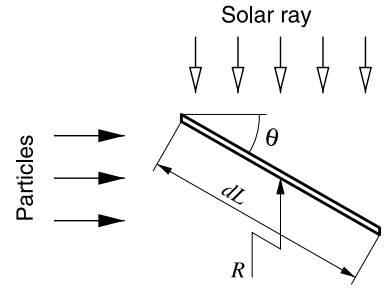

第 3 図＼cjkstart壁面の幾何モデル

第 1 表 高層大気の特性と軌道速度

\begin{tabular}{|c|c|c|c|c|c|c|}
\hline \multirow{2}{*}{$\begin{array}{l}\text { 高度 } \\
(\mathrm{km})\end{array}$} & \multicolumn{3}{|c|}{ モル分率 } & \multirow{2}{*}{$\begin{array}{c}\text { 数密度 } \mathrm{a} \\
\left(\mathrm{m}^{-3}\right)\end{array}$} & \multirow{2}{*}{$\begin{array}{c}\text { 温度 } \\
(\mathrm{K})\end{array}$} & \multirow{2}{*}{$\begin{array}{c}\text { 軌道速度 } \\
(\mathrm{km} / \mathrm{s})\end{array}$} \\
\hline & $\mathrm{N}_{2}$ & $\mathrm{O}_{2}$ & $\mathrm{O}$ & & & \\
\hline 100 & 0.788 & 0.176 & 0.036 & $1.45^{+19}$ & 170 & 7.85 \\
\hline 120 & 0.731 & 0.076 & 0.193 & $4.60^{+17}$ & 382 & .84 \\
\hline 140 & 0.650 & 0.044 & 0.306 & $8.73^{+16}$ & 682 & 7.82 \\
\hline 160 & 0.579 & 0.034 & 0.387 & $3.45^{+16}$ & 862 & 7.81 \\
\hline 180 & 0.513 & 0.027 & 0.459 & $1.75^{+16}$ & 968 & 7.80 \\
\hline 210 & 0.422 & 0.020 & 0.559 & $7.85^{+15}$ & 1054 & 7.78 \\
\hline 240 & 0.338 & 0.014 & 0.648 & $4.00^{+15}$ & 1093 & 7.76 \\
\hline 270 & 0.265 & 0.010 & 0.725 & $2.19^{+15}$ & 1111 & 7.75 \\
\hline 300 & 0.204 & 0.007 & 0.789 & $1.26^{+15}$ & 1120 & 7.73 \\
\hline
\end{tabular}

${ }^{\mathrm{a}} 1.45^{+19}$ という表記は $1.45 \times 10^{+19}$ の意味.

め, 太陽光線は衛星の側面，すなわち流入粒子と垂直方向 から照射すると仮定する．流入する粒子のエネルギーは全 て壁面に与えられると仮定し，表面温度が太陽光，粒子衝 突，および表面放射の平衡で決定されると仮定すると，

$$
\begin{aligned}
& 2 \pi R d L \sin \theta \rho v\left(v^{2} / 2+h\right)+2 R d L \cos \theta \eta_{\mathrm{s}} P_{\mathrm{s}} \\
& \quad=2 \pi R d L\left(\epsilon_{\mathrm{i}}+\epsilon_{\mathrm{o}}\right) \sigma T_{\mathrm{W}}^{4}
\end{aligned}
$$

が成り立つ．壁面内側が衛星コアと放射平衡に達している 場合は $\epsilon_{\mathrm{i}}=0$ とおいて片面放射平衡温度が得られる.この 場合壁面温度は

$$
T_{\mathrm{W}}=\left[\frac{\rho v\left(v^{2} / 2+h\right) \sin \theta+\left(\eta_{\mathrm{s}} P_{\mathrm{s}} / \pi\right) \cos \theta}{\epsilon_{\mathrm{o}} \sigma}\right]^{1 / 4}
$$

で与えられる。

第 1 表に示したのは, MSISE-90 大気モデル (Mass Spectrometer-Incoherent Scatter Model) $)^{7)}$ を用いて算出 した, 緯度 0 度，経度 0 度，2002 年 1 月 1 日 $0: 00$ 時 点における高層大気の特性である. 各高度における軌道速 度も併せて記した . 高層大気の特性は季節や緯経度によっ て変化するが, 弚の程度は緩やかであるため, 以下本論文 を通して第 1 表の大気モデルを代表值として議論を行うこ とにする .この表の值を用いて式 (11)により幾つかの高度 について壁面温度を決定した結果を第 4 図に示す .ただし $P_{\mathrm{s}}=1370 \mathrm{~W} / \mathrm{m}^{2}, \epsilon_{\mathrm{o}}=0.8$ とし, 太陽光吸収係数として $\eta_{\mathrm{s}}=0.8$ および 0.2 の 2 ケースについて結果を示した . 前 者は太陽電池表面の代表的な値であり ${ }^{8)}$, 後者は積極的に 放射断熱を行う場合に用いられる反射率の高い壁面を想定 している。

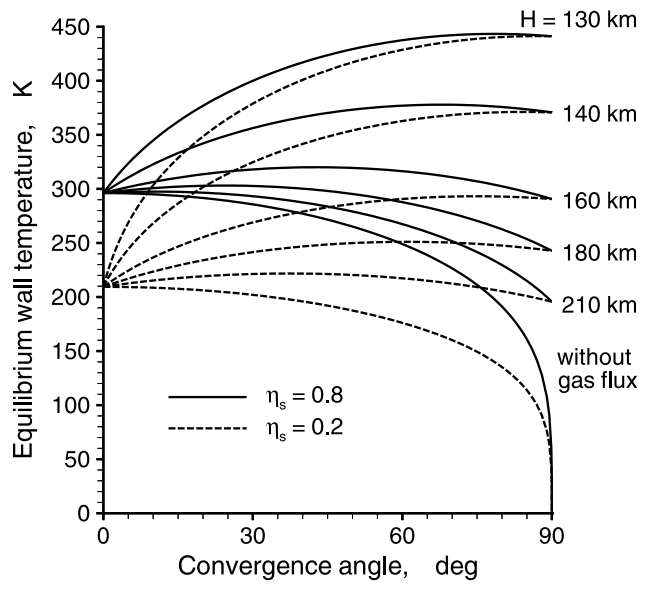

第 4 図＼cjkstart各高度における輻射平衡壁面温度

第 4 図によると，衛星側壁 ( $\theta=0^{\circ}$ に相当) は粒子衝突 の影響を受けないため, 光の輻射平衡温度は高度によらず太 陽光吸収率のみに依存し, 概ね 200〜300 K と通常の衛星の 場合と同樣である.一方, 衛星コア正面部の温度 $\left(\theta=90^{\circ}\right.$ に相当) は太陽光吸収率によらず, 高度の低下とともに急激 に上昇する. 弚れ以外の場合，すなわち $0<\theta<90^{\circ}$ の範 囲では, 輻射平衡壁面温度は太陽光と粒子双方による加熱 を受けるため，太陽光吸収率と高度の双方に依存する.壁 温に対する制約条件はミッションの目的にもよるため一概 には判定できないが，ABIE を極低軌道での諸々の観測ミッ ションに適用することを考えると観測器機が使用できる温 度が上限と考えられ, 光の温度は $400 \mathrm{~K}$ 程度か限界であろ う .このことから ABIE の使用できる高度下限は $140 \mathrm{~km}$ 程度と予想される。

\section{3. モンテカルロ直接法による空気取込性能評価}

イオンエンジンでは放電室密度をある程度高くしなけれ ば推進剤を効率よく電離することができなくなり，推進阂 利用効率や電離効率が低下してしまう．軌道高度の上昇と ともに雾囲気密度は低下するため, ABIE では空気取込の 際にラム圧縮を行う必要があり，いかに圧縮比を高くして 放電室の密度を上昇できるかが運用可能な高度上限を決め る条件となる。これに加えて，式 (8)，(9)において ABIE の加速電圧と加速電力は空気取込効率 $\eta_{\mathrm{i}}$ に強く依存し， $\eta_{\mathrm{i}}$ をできるだけ大きくすることが ABIE の作動条件を緩和 し，運用可能範囲を拡大することがわかる．このように空 気取込性能は ABIE の性能に最も影響を与える要素の一 つである．本稿では空気取込性能を定量的に評価するため に，モンテカルロ直接法 (DSMC) による希薄流れの解析 を行った。

3.1 DSMC モデル 本研究では希薄流机解析のため に RARAC-3D コード9,10)を用いた . RARAC-3D はア ルゴリズムに Bird の no-time counter 法 ${ }^{11)}$ を用い , 分子 衝突判定にはVHS (variable hard sphere) モデル11) 用いた 3 次元の反応性希薄気流解析汎用コードである.解 析では第 2 図に示す ABIE モデルを用い, 固定長として 
$R_{1}=1 \mathrm{~m}, L_{1}=2 \mathrm{~m}, L_{2}=0.2 \mathrm{~m}$ ，および $R_{3}=0.8 \mathrm{~m}$ とおいた .これに対し，インテークダクト縦横比か空気取込 性能に与える影響を調べるために $R_{2}$ を $1.05 \mathrm{~m}$ から $2.0 \mathrm{~m}$ まで変化させた . この場合 $\chi$ は 40 から 2 まで変化する 飛行高度として $140,160,180,210$, および $240 \mathrm{~km}$ につ いて，また飛行迎角として $0,2.5,5,7.5,10,15^{\circ}$ の場合に ついて解析を行った . 各高度における飛行速度および大気 条件は第 1 表の値を用いた .代表長として $R_{1}(=1 \mathrm{~m})$ を 用いると, 高度 $140 \mathrm{~km}$ 以上では主流, 放電室内のいずれ においてもクヌーセン数は 10 以上となり流れは自由分子 流とみなせる .このため気相では分子間衝突はほとんど起 こらず，衝突モデルに内在する不確実性が解析結果に与え る影響は無視できる . 自由分子流においては, 空気取込過 程の解析を行う上で重要となるのが, 壁面での散乱モデル である．本解析では壁面を不活性，非触媒性であると仮定 し, 衝突粒子の壁面における熱適合係数 (accommodation factor) を $\gamma$ で定義し，壁面に衝突する粒子は確率 $\gamma$ で壁 面温度と平衡な Maxwell 速度分布を持つ粒子としてラン ダム方向に散乱され (完全拡散散乱)，弚れ以外の場合は壁 面て鏡面反射されるというモデルを用いた . この時 $\gamma$ を 0 から 1 まて変化させ, また第 4 図の検討結果にもとづいて 壁面温度を 150 から $500 \mathrm{~K}$ まで変化させることで, 壁面 条件が空気取込性能に与える影響について検討した。

計算領域は衛星前方 $\left(0<x<3 L_{1}\right.$ かつ $\left.\sqrt{y^{2}+z^{2}}<3 R_{2}\right)$ の領域およびインテークダクト, 放電室内部のみとし, 衛 星外部領域 $\left(R_{2}<\sqrt{y^{2}+z^{2}}\right.$ かつ $\left.x<0\right)$ は除外した（第 2 図参照). 境界面 $R_{2}<\sqrt{y^{2}+z^{2}}$ かつ $x=0$ においては簡 単のため真空への流出条件を課した . 計算領域は $z>0$ の みとし $z=0$ 面においては対称条件を課したが, ABIE の 飛行迎角が $0^{\circ}$ の場合は計算時間節約のためさらに $y<0$ を除外し $y=0$ 面で対称条件を課した . 衛星前方では粒子 はほぼ無衝突であるため, 衛星前方の計算領域の大きさが 計算結果に影響を与えないことは確認されている．

空気取込効率 $\eta_{\mathrm{i}}$ を評価するには，背面板（あるいはスク リーングリッド) からのビーム引出しを考慮する必要があ る. 本稿では簡単化のため粒子の電離過程や荷電粒子に働 く静電力を考慮せず, ビーム引出しにおいては, 背面板に 到達した粒子は透過率 $\eta_{\mathrm{t}}$ で背面板を透過し, 弚れ以外は上 記の壁面散乱モデルで散乱され，背面板より下流から粒子 の逆流は無いとする簡易な強制ビーム引出しモデルを採用 した .このモデルでは $\eta_{\mathrm{t}}$ は背面板面積 $\left(=\pi R_{3}^{2}\right)$ に対する スクリーングリッドのイオン捕獲面の総面積（スクリー ングリッド穴の総面積) の比に等しい . ビーム断面積は近 似的に $\pi R_{2}^{2} \beta \eta_{\mathrm{t}}$ で与えられ, ビーム電流密度は式 (7)より

$$
i=\rho v \alpha \eta_{\mathrm{i}} \eta_{\mathrm{u}} e / m \beta \eta_{\mathrm{t}}
$$

で与えられる。

3.2 解析結果 解析においては事前にグリッドスタディ を行い, 解析結果に格子の影響が表れないように十分な格 子を配置した．しかしすでに述べたように，気流は全域で ほぼ自由分子流と見なすことができるため，格子の影響は
第 2 表 各高度における圧縮比と放電室密度 (迎角 $0^{\circ}, \chi=10, \gamma=1$, $\left.T_{\mathrm{W}}=300, \eta_{\mathrm{t}}=0\right)$

\begin{tabular}{ccc}
\hline 高度 $(\mathrm{km})$ & 圧縮比 $G_{0}$ & 放電室密度 $\left(\mathrm{m}^{-3}\right)$ \\
\hline 140 & $180.1 \pm 3.2$ & $(1.57 \pm 0.03) \times 10^{19}$ \\
160 & $178.9 \pm 3.2$ & $(6.17 \pm 0.11) \times 10^{18}$ \\
180 & $176.9 \pm 3.2$ & $(3.10 \pm 0.06) \times 10^{18}$ \\
210 & $173.8 \pm 3.1$ & $(1.36 \pm 0.02) \times 10^{18}$ \\
240 & $167.4 \pm 3.0$ & $(6.70 \pm 0.12) \times 10^{17}$ \\
\hline
\end{tabular}

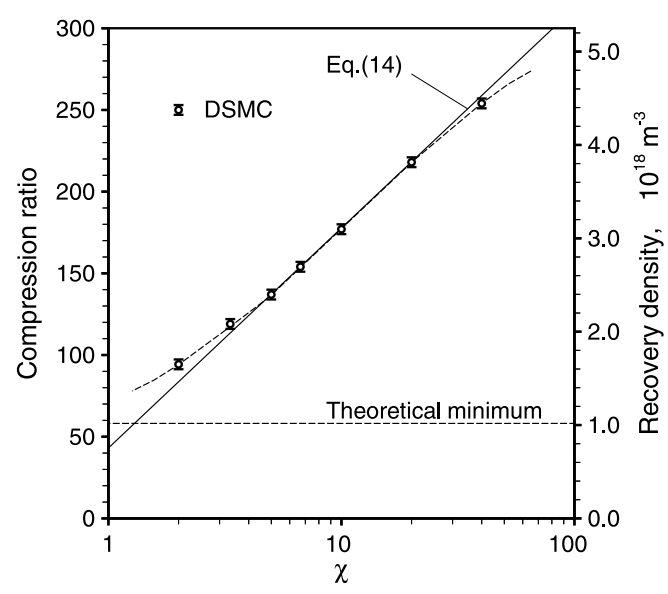

第 5 図 圧縮比に対するインテークダクト縦横比の影響 (高度 $180 \mathrm{~km}$ ， 迎角 $0^{\circ}, \gamma=1, T_{\mathrm{W}}=300, \eta_{\mathrm{t}}=0$ )

ほとんど解析結果に表れない，典型的な高度 $180 \mathrm{~km}$ で迎 角を持つ場合の解析では, 格子点数は約 43 万点程度, 粒 子サンプル数は解析終了時点で 600 万程度であり，収束ま でに約 50 万ステップの計算を必要とした . 流れ場の定常 解はアンサンブル平均で決定され，本解析では統計的誤差 として密度に $\pm 2 \%$ 程度の誤差を含んでいる．流れ場の樣 子など定性的な議論は紙面の都合上割愛したが, 興味ある 読者は先の報告 ${ }^{5,6)}$ を参照されたい，以下，ABIE の空気 取込性能について定量的な議論を行う.

3.3 密度の影響 数值解析で得られた流れ場において， 放電室内背面板中心での密度を放電室密度とし，一樣流の 密度に対する放電室密度の比を圧縮比 $G$ として定義した。 第 2 表に迎角 $0^{\circ}, \chi=10, \gamma=1, T_{\mathrm{W}}=300, \eta_{\mathrm{t}}=0$ の場 合の圧縮比と放電室密度を各高度について示した . 圧縮比 は熱拡散速度が大きいほど低下すると考えられるため，高 度の上昇とともに気体温度が高くなり，また平均分子量が 小さくなるにつれて (第 1 表参照) 圧縮比は徐々に低下す る.従って，設計を行うレベルで正確に圧縮比を予測する場 合は，正確な大気の組成を用いる必要があるといえる．し かし定性的には, 圧縮比は高度の变化に対して鈍感である。

3.4 インテークダクト縱横比の影響 インテークダクト 縦横比が圧縮比に与える影響を調べるために, 高度 $180 \mathrm{~km}$, 迎角 $0^{\circ}, \gamma=1, T_{\mathrm{W}}=300, \eta_{\mathrm{t}}=0$ の場合において $\chi を$ 変化させて計算を行った . 第 5 図に圧縮比, 放電室密度と $\chi$ の関係を示す . 圧縮比は $\chi$ の増加とともに増加するが $\chi$ がある程度以上大きくなると圧縮比の増加は頭打ちとなる． この理由は，流入する粒子が群速度の垂直方向に熱速度を 
持っているためである . 高度 $180 \mathrm{~km}$ を例にとってみると， 温度 $968 \mathrm{~K}$ での室素分子, 酸素原子の熱速度の平均值は光

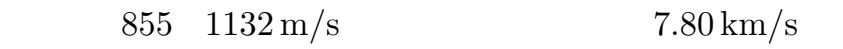
対するビーム拡がり角は光れ午れ $12.5,16.5^{\circ}$ となり，気 流はかなりの拡散ビームであることがわかる .このため攵 クトの縦横比がある程度以上大きくなると, 粒子反射板に 到達する前にダクト壁面で散乱される粒子か増加し, 放電 室まて到達する粒子数が相対的に減少するため, 圧縮比の 増加は頭打ちとなるのである .

一方 $G$ の下限としては $\chi$ が 0 となる極限を考えれば良 い.この場合，インレットに $x>0$ の方向から流入する自 由分子流の流束と, 温度 $T_{\mathrm{W}}$ で熱的平衡状態にある放電室 内部の気体がインレット面を $x>0$ の方向へ通過する流束 がバランスするので

$$
\frac{\rho_{\mathrm{c}}}{4} \sqrt{\frac{8 k T_{\mathrm{W}}}{\pi m}}=\rho v
$$

これより压縮比の下限は $G=\rho_{\mathrm{c}} / \rho=4 v \sqrt{\pi m / 8 k T_{\mathrm{W}}}$ で 与えられる. 高度 $180 \mathrm{~km}$ では $G=59$ となる.

上記の結果から，圧縮比を増加するためには $\chi$ を大きく することが望ましいといえる．しかし $\chi$ を大きくすると 式 (2)より $\alpha$ か減少し, 式 (8)，(9) より加速電圧や加速 電力か増加してしまうので, $\alpha$ が減少しないように $L_{1}$ を 大きくしなければならず, 衛星全長が増加し推重比が低下 してしまう. 例えば $\alpha=0.3$ の下で $\chi=40$ を実現しよう とする場合 $L_{1} / R_{1}=7.81$ としなければならず，衛星は極

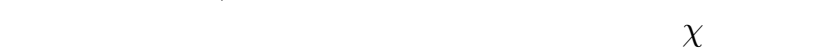
すると失速迎角が低下するため, 衛星の制御が困難になる 従って現実的な $\chi$ の範囲としては $5<\chi<20$ 程度であろ う.この範囲においては圧縮比は第 5 図に示すように

$$
G=G_{0}(0.244+0.330 \ln \chi)
$$

で近似できる．ただし $G_{0}$ は第 2 表に示された基準条件で 得られる圧縮比であり，高度 $180 \mathrm{~km}$ では $G_{0}=176.9$ で ある

3.5 迎角の影響 飛行迎角が圧縮比に与える影響を調べ るために，高度 $180 \mathrm{~km}, \chi=10, \eta_{\mathrm{t}}=0, \gamma=1, T_{\mathrm{W}}=300$ の場合について迎角を変化させて圧縮比を求めた . 結果を 第 6 図に示す.解析結果によると, 迎角が $5^{\circ}$ から $10^{\circ}$ へ増 加する際に圧縮比が急激に減少していることがわかる．こ の現象は自由分子流が粒子反射板に到達する前にダクト壁 面に衝突，散乱してしまうことに起因する．これを説明す るためにダクトを縦横比が 10 の矩形で近似すると，対角 線と長辺の成す角は $\arctan (1 / 10)=5.7^{\circ}$ となる.すなわ ち迎角が $5.7^{\circ}$ となるあたりから，粒子は反射板に衝突す る前にダクト側壁に衝突するようになる $\gamma=1$ では粒子 は衝突点から任意の方向に拡散してしまうため, 側壁での 散乱は実質的に $\chi$ が小さくなるのと同じ効果を発生する . このように，迎角がダクトの特性角 $\arctan (1 / \chi)$ 以上に なると圧縮比は急減するので, 衛星の運用上は注意を要す る.実際には，本解析で用いたダクトは機体軸回りに曲率

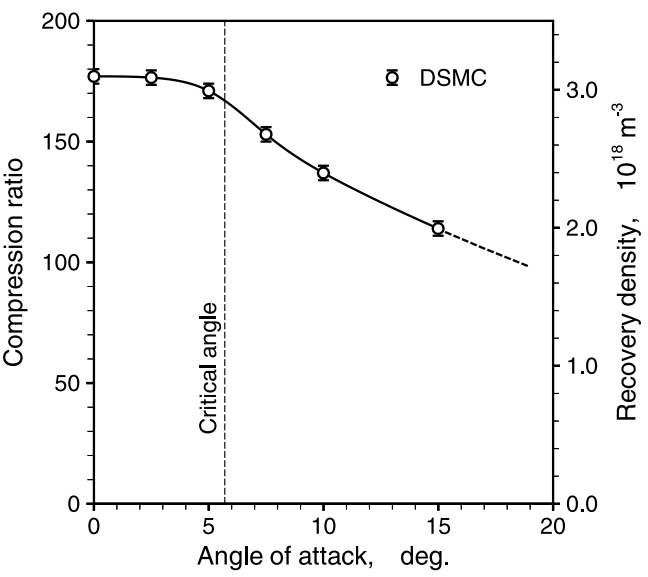

第 6 図 圧縮比に対する迎角の影響（高度 $180 \mathrm{~km}, \chi=10, \gamma=1$, $\left.T_{\mathrm{W}}=300, \eta_{\mathrm{t}}=0\right)$

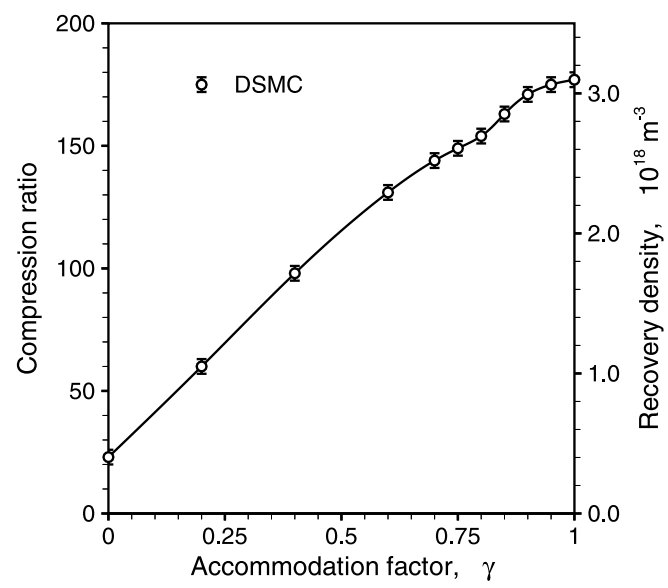

第 7 图 圧縮比に対する壁面熱適合係数の影響 (高度 $180 \mathrm{~km}$, 迎角 $0^{\circ}, \chi=10, T_{\mathrm{W}}=300, \eta_{\mathrm{t}}=0$ )

を持っているため迎角の増加に対する圧縮比の減少は矩形 ダクトの場合よりも緩やかで, 第 5 図においても圧縮比の 急激な低下をもたらす迎角の值はダクトの特性角 $5.7^{\circ}$ よ りやや大きくなっている．失速迎角に関する制限を緩和し， かつ圧縮比を最大限に増加させる観点からは, 壁面による 流入粒子の散乱ができるだけ起きないように側壁の断面積 を最小限とし，かつ対称性を保持するのか望ましいといえ る.従って ABIE のインテークダクトの形状としては，円 柱状の衛星コア回りに円筒シェルを配するという，本稿で 採用した形態か望ましいといえる．外筒シェルを支持する 構造部材はできるだけ小さい方か望ましい，可能であれば 支持機構は放電室内部に設け, ダクト内の障害物はできる だけ取り除くべきである .

3.6 壁面条件の影響 壁面条件が圧縮比に与える影響 を調べるために，高度 $180 \mathrm{~km}$ ，迎角 $0^{\circ}, \chi=10, \eta_{\mathrm{t}}=0$ の場合において $\gamma$ および $T_{\mathrm{W}}$ を変化させて計算を行った . 結果を第 7,8 図に光れ示す.圧縮比は $\gamma, T_{\mathrm{W}}$ のいず れにも強く依存することがわかる.

熱適合係数は壁面の状態, 材質, 気体種, 温度に依存す るため詳細な議論は難しいが, この值を工学的に制御する 


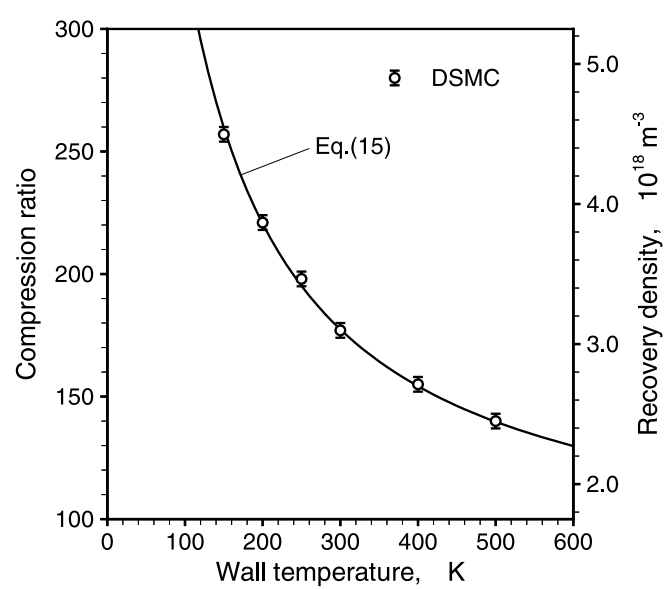

第 8 図 圧縮比に対する壁面温度の影響（高度 $180 \mathrm{~km}$, 迎角 $0^{\circ}$, $\chi=10, \gamma=1, \eta_{\mathrm{t}}=0$ )

ことは容易ではなく，一般的には $0.8 〜 1.0$ の値をとると 考えられている. 従って第 7 図によると，圧縮比としては $\gamma=1$ の場合の $87 \%$ 值を起こり得る安全側の值として用 いれば良いといえよう．一方壁面温度に関する圧縮比の依 存性は, DSMC 解析結果を $T_{\mathrm{W}}$ の関数として

$$
G=G_{0}\left[189 /\left(T_{\mathrm{W}}+33\right)+0.435\right]
$$

と近似できる (第 8 图参照).ただし $150<T_{\mathrm{W}}<500 \mathrm{~K}$ に限る . 圧縮比は温度の低下とともに急激に上昇するため できるだけ壁面温度を低下させることが運用上望ましい，

3.7 ビーム引出しの影響 以上の議論は, スクリーング リッドにおいてイオンビームの引出しを行わず, 希薄気流 がキャビティ内でどの程度密度上昇するか, という結果を 与えたに過ぎない．実際にはスクリーングリッドからビー ム引出しを行うためダクト内に一方向性の流れが生じ，こ の結果として放電室密度は低下する .この影響を調べるた めに，高度 $180 \mathrm{~km}$, 迎角 $0^{\circ}, \chi=10, \gamma=1, T_{\mathrm{W}}=300$ の場合について， $\eta_{\mathrm{t}}$ を変化させて圧縮比と空気取込効率 $\eta_{\mathrm{i}}$ を求めた .ただし $\eta_{\mathrm{i}}$ は，インレットからダクト内に流入す る粒子の流束を $\Gamma_{0}$ ，拡散によりインレットからダクト外に 逆流する流束を $\Gamma_{1}$ とおいて， $\eta_{\mathrm{i}}=1-\Gamma_{1} / \Gamma_{0}$ で与えた . 解析結果を第 9 図に示す.

透過率 $\eta_{\mathrm{t}}$ を増加させると空気取込効率は急激に増加する のに対して, 圧縮比は急激に減少する。解析結果は $\eta_{\mathrm{t}} \leq 0.3$ において近似式

$$
\begin{aligned}
G & =G_{0}\left[1-0.772\left(1-e^{-8.15 \eta_{\mathrm{t}}}\right)\right] \\
\eta_{\mathrm{i}} & =0.475\left(1-e^{-8.15 \eta_{\mathrm{t}}}\right)
\end{aligned}
$$

で精度良く再現できる (第 9 図参照) . 式 (16)，(17) から $\eta_{\mathrm{t}} \leq 0.3$ においては

$$
G=G_{0}\left(1-1.625 \eta_{\mathrm{i}}\right)
$$

が得られ，圧縮比は空気取込効率に対してほほ線形に減少 するという関係が成り立つ．すなわち圧縮比と空気取込効 率は相反する特性を示すため, ABIE の設計においては最 適な値を選ぶ必要があるといえる。

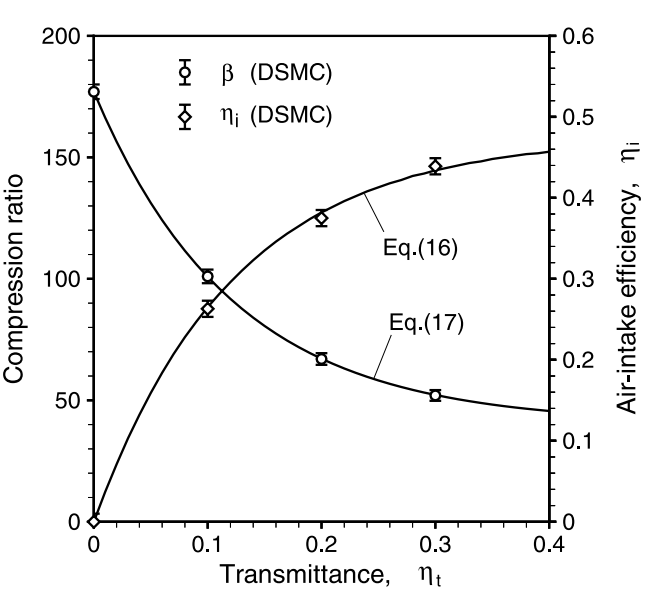

第 9 図 圧縮比と空気取込効率の透過率に対する依存性 (高度 $180 \mathrm{~km}$, 迎角 $0^{\circ}, \chi=10, \gamma=1, T_{\mathrm{W}}=300$ )

\section{4. 空気吸込式イオンエンジンの成立性検討}

以上得られた結果をもとに, 空力的な立場から ABIE の 成立性について検討を行う，最適設計については本稿の範 囲を越えてしまうため別稿に委ねるとして，以下では基礎 的な検討に留める . まず, 本解析で取扱ってきた独立な可変 パラメータについて整理すると，飛行高度， $C_{\mathrm{D}}, \alpha, \beta, \chi, \theta$, $\eta_{\mathrm{u}}, \eta_{\mathrm{s}}, \epsilon_{\mathrm{o}}$, および $\eta_{\mathrm{t}}$ である .これら全てを変化させると膨 大な場合についての検討が必要となるため，以下の検討では $\eta_{\mathrm{u}}=0.8, \eta_{\mathrm{s}}=0.2, \epsilon_{\mathrm{o}}=0.8$ は一定とし, $\alpha+\beta=0.9$ と おく. 抗力係数は $\gamma=1$ に対応する理論值である $C_{\mathrm{D}}=2$ を用いる．また粒子反射板の壁温を式 (15)の $T_{\mathrm{W}}$ として 用い, 現実的な収束角として $\theta=45^{\circ}$ とする. 以上の条件 下で, 各高度において形状パラメータ $\alpha, \chi$, および透過率 $\eta_{\mathrm{t}}$ を変化させた場合の放電室密度, イオンビーム電流密度, 加速電圧, および衛星の単位断面積当たり必要な加速電力 $\left(p_{\mathrm{A}} \equiv P_{\mathrm{A}} / \pi R_{2}^{2}\right)$ を評価することにする．

4.1 放電室密度条件 各高度において第 1 表により大 気の組成, 密度, 温度, および軌道速度が決まるので, 式 (11)により $T_{\mathrm{W}}$ が一意的に決まる.飛行迎角 $0^{\circ}$ の場合 の圧縮比は，式 (14)，(15)，(16)，および $\gamma$ に関する考察 から

$$
\begin{aligned}
G= & 0.87 G_{0}(0.244+0.330 \ln \chi) \\
& \times\left[189 /\left(T_{\mathrm{W}}+33\right)+0.435\right] \\
& \times\left[1-0.772\left(1-e^{-8.15 \eta_{\mathrm{t}}}\right)\right]
\end{aligned}
$$

により与えられるとすると, 各高度における放電室密度 $(=\rho G)$ は結局 $\chi$ と $\eta_{\mathrm{t}}$ のみに依存する .これにもとづいて 放電室密度を計算した結果を第 3 表に示す . ただし式 (19) は $\eta_{\mathrm{t}}=0.4$ でも成り立つと仮定し，また失速迎角を考慮 して $\chi$ の最大值は 20 とした .これに対応する失速迎角は $\arctan (1 / 20)=2.9^{\circ}$ となる .

HAYABUSA でも用いられているマイクロ波放電型のイ オンエンジンを例にとると，イオンエンジンの適正な運用 を行うためには放電室密度が $10^{18} \sim 10^{19} \mathrm{~m}^{-3}$ である必要 
第 3 表 放電室密度一覧

\begin{tabular}{crcccc}
\hline $\begin{array}{c}\text { 高度 } \\
(\mathrm{km})\end{array}$ & \multirow{2}{*}{$\chi$} & \multicolumn{4}{c}{ 放電室密度 $\mathrm{a}\left(\mathrm{m}^{-3}\right)$} \\
\cline { 3 - 6 } & & $\eta_{\mathrm{t}}=0.1$ & 0.2 & 0.3 & 0.4 \\
\hline 140 & 5.0 & $5.59^{+18}$ & $3.72^{+18}$ & $2.90^{+18}$ & $2.53^{+18}$ \\
140 & 10.0 & $7.24^{+18}$ & $4.82^{+18}$ & $3.75^{+18}$ & $3.28^{+18}$ \\
\hline 160 & 5.0 & $2.42^{+18}$ & $1.61^{+18}$ & $1.25^{+18}$ & $1.09^{+18}$ \\
160 & 10.0 & $3.13^{+18}$ & $2.09^{+18}$ & $1.62^{+18}$ & $1.42^{+18}$ \\
160 & 15.0 & $3.55^{+18}$ & $2.36^{+18}$ & $1.84^{+18}$ & $1.61^{+18}$ \\
\hline 180 & 5.0 & $1.29^{+18}$ & $8.59^{+17}$ & $6.68^{+17}$ & $5.84^{+17}$ \\
180 & 10.0 & $1.67^{+18}$ & $1.11^{+18}$ & $8.66^{+17}$ & $7.56^{+17}$ \\
180 & 20.0 & $2.05^{+18}$ & $1.37^{+18}$ & $1.06^{+18}$ & $9.28^{+17}$ \\
\hline 190 & 10.0 & $1.27^{+18}$ & $8.48^{+17}$ & $6.59^{+17}$ & $5.76^{+17}$ \\
190 & 15.0 & $1.44^{+18}$ & $9.61^{+17}$ & $7.47^{+17}$ & $6.53^{+17}$ \\
190 & 20.0 & $1.56^{+18}$ & $1.04^{+18}$ & $8.09^{+17}$ & $7.07^{+17}$ \\
\hline 200 & 10.0 & $9.87^{+17}$ & $6.57^{+17}$ & $5.11^{+17}$ & $4.46^{+17}$ \\
200 & 15.0 & $1.12^{+18}$ & $7.45^{+17}$ & $5.79^{+17}$ & $5.06^{+17}$ \\
200 & 20.0 & $1.21^{+18}$ & $8.07^{+17}$ & $6.28^{+17}$ & $5.48^{+17}$ \\
\hline a $5.59^{+18}$ という表記は $5.59 \times 10^{+18}$ の意味 .
\end{tabular}

がある. 第 3 表によると，高度 $140 \mathrm{~km}$ ではいずれのヶー スでも密度が $10^{18}$ より十分に大きく, 放電室密度に対す る制約は発生しない，高度が上昇すると密度 $10^{18} \mathrm{~m}^{-3}$ を 達成できるケースが限られるようになり，高度 $200 \mathrm{~km}$ よ り高高度では $\chi \leq 20$ で十分な密度を達成できなくなる。

4.2 加速電圧とビーム電流密度条件 次に各高度にお ける加速電圧, 単位断面積当たりの加速電力, イオンビー 么電流密度であるが, $\eta_{\mathrm{i}}$ が式 $(17)$ より $\eta_{\mathrm{t}}$ の関数となるた め, これらは $\chi$ には依存せず $\alpha$ および $\eta_{\mathrm{t}}$ のみに依存す る. 光こで各高度におけるこれらの值を $\eta_{\mathrm{t}}$ と $\alpha$ を変化さ せて計算した .一般的なイオンエンジンを例にとり，加速 電圧として $1 \mathrm{kV}$ 以下, ビーム電流密度として $4 \mathrm{~mA} / \mathrm{cm}^{2}$ 以下という条件を設け，この条件を満足させる $\eta_{\mathrm{t}}$ と $\alpha$ の 組み合わせを検索した結果を第 4 表に示す .

一般に $\alpha$ の増加とともに加速電圧は減少するが電流密度 は増加し，また $\eta_{\mathrm{t}}$ の増加とともに加速電圧と電流密度は ともに減少する．従ってできるだけ大きな $\eta_{\mathrm{t}}$ をとることが 望ましいが, 第 3 表に示すように密度の制約から各高度で 許容される $\eta_{\mathrm{t}}$ の最大值は決まっているため, 各高度におい て加速電圧・ビーム電流密度条件を満足できる $\alpha, \eta_{\mathrm{t}}$ の範 囲には限りがあることになる．高度 $140 \mathrm{~km}$ では $\eta_{\mathrm{t}} \leq 0.3$ において条件を満足できる解は存在せず， $\eta_{\mathrm{t}}=0.4$ の時に $\alpha=0.25$ で条件が満足されている.ただし高度 $140 \mathrm{~km} に$ おいては第 3 表に示すように密度にまだ十分な余裕がある ため本解析で検討していない $\eta_{\mathrm{t}}>0.4$ も許容されると考

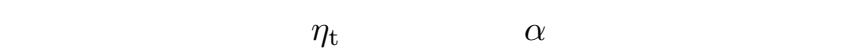
いて加速電圧・ビーム電流密度条件が満足されると推察さ れる.高度 $160,180 \mathrm{~km}$ においては条件を満足する $\eta_{\mathrm{t}}$ や $\alpha$ の範囲は広く，高度が上昇するにつれて許容される $\eta_{\mathrm{t}}$ の 範囲が狭くなり，結果として条件を満足できる場合か限ら れるようになる 。

4.3 ABIE の基本仕様 以上の結果にもとづいて ABIE の基本的な仕樣を検討してみる. 空気力学的な立場 からは, ABIE は高度 140〜200 km で成立可能であると
第 4 表 加速電圧 , 単位断面積当たりの加速電力 , およびイオンビー 么電流密度一覧

\begin{tabular}{cccrcc}
\hline $\begin{array}{c}\text { 高度 } \\
(\mathrm{km})\end{array}$ & $\eta_{\mathrm{t}}$ & $\alpha$ & \multicolumn{1}{c}{$V_{\mathrm{A}}$} & $\begin{array}{c}p_{\mathrm{A}} \\
\left(\mathrm{VW} / \mathrm{m}^{2}\right)\end{array}$ & $\begin{array}{c}i \\
\left(\mathrm{~mA} / \mathrm{cm}^{2}\right)\end{array}$ \\
\hline 140 & 0.3 & 0.20 & 1612.7 & 12.26 & 3.62 \\
140 & 0.3 & 0.25 & 1032.2 & 9.80 & 4.87 \\
\cline { 2 - 6 } 140 & 0.4 & 0.20 & 1454.7 & 11.64 & 2.86 \\
140 & 0.4 & 0.25 & 931.0 & 9.31 & 3.85 \\
140 & 0.4 & 0.30 & 646.5 & 7.76 & 5.00 \\
\hline 160 & 0.1 & 0.25 & 2649.0 & 6.05 & 3.51 \\
160 & 0.1 & 0.30 & 1839.6 & 5.04 & 4.57 \\
\cline { 2 - 6 } 160 & 0.2 & 0.25 & 1272.8 & 4.19 & 2.54 \\
160 & 0.2 & 0.30 & 883.9 & 3.50 & 3.30 \\
160 & 0.2 & 0.35 & 649.4 & 3.00 & 4.19 \\
\cline { 2 - 6 } 160 & 0.3 & 0.20 & 1541.6 & 4.62 & 1.43 \\
160 & 0.3 & 0.25 & 986.6 & 3.69 & 1.92 \\
160 & 0.3 & 0.40 & 385.4 & 2.31 & 3.99 \\
160 & 0.3 & 0.45 & 304.5 & 2.05 & 4.99 \\
160 & 0.4 & 0.20 & 1390.5 & 4.38 & 1.13 \\
160 & 0.4 & 0.25 & 889.9 & 3.51 & 1.52 \\
160 & 0.4 & 0.45 & 274.7 & 1.95 & 3.94 \\
160 & 0.4 & 0.50 & 222.5 & 1.75 & 4.93 \\
\hline 180 & 0.1 & 0.35 & 1296.2 & 2.10 & 2.95 \\
180 & 0.1 & 0.40 & 992.4 & 1.84 & 3.71 \\
180 & 0.1 & 0.45 & 784.1 & 1.64 & 4.64 \\
\hline 180 & 0.2 & 0.25 & 1220.7 & 2.04 & 1.29 \\
180 & 0.2 & 0.30 & 847.7 & 1.70 & 1.67 \\
180 & 0.2 & 0.45 & 376.8 & 1.13 & 3.34 \\
180 & 0.2 & 0.50 & 305.2 & 1.02 & 4.18 \\
\hline 180 & 0.3 & 0.20 & 1478.5 & 2.25 & 0.72 \\
180 & 0.3 & 0.25 & 946.3 & 1.80 & 0.97 \\
180 & 0.3 & 0.55 & 195.5 & 0.82 & 3.98 \\
180 & 0.3 & 0.60 & 164.3 & 0.75 & 5.06 \\
\hline 190 & 0.1 & 0.35 & 1270.1 & 1.54 & 2.21 \\
190 & 0.1 & 0.40 & 972.4 & 1.35 & 2.78 \\
190 & 0.1 & 0.45 & 768.3 & 1.20 & 3.47 \\
190 & 0.1 & 0.50 & 622.4 & 1.08 & 4.34 \\
\hline 190 & 0.2 & 0.25 & 1196.1 & 1.50 & 0.96 \\
190 & 0.2 & 0.30 & 830.7 & 1.25 & 1.25 \\
190 & 0.2 & 0.55 & 247.1 & 0.68 & 3.93 \\
\hline & 0.2 & 0.60 & 207.7 & 0.62 & 5.01 \\
\hline 0.1 & 0.35 & 1244.9 & 1.16 & 1.69 \\
100 & 0.1 & 0.40 & 953.1 & 1.01 & 2.13 \\
0.50 & 610.0 & 0.81 & 3.32 \\
1 & 0.55 & 504.1 & 0.74 & 4.18 \\
\hline
\end{tabular}

予測される . 高度 $140 \mathrm{~km}$ においては雰囲気密度が高いこ

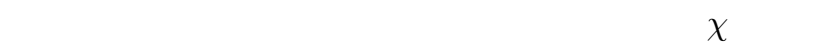
くすることが可能で, また $\eta_{\mathrm{t}}$ をできるだけ大きくして加速 電圧とビーム電流密度を下げるほうが良い，高度 $200 \mathrm{~km}$ では逆にできるだけ $\chi$ を大きくして高圧縮比を実現し，許 容される $\eta_{\mathrm{t}}$ の上限值の中で最適の $\alpha$ を選択する . 高高度 では $\alpha$ の最適值は，低高度の場合よりも大きな値となる (第 4 表参照) . 以上の基準に従い, ABIE が実現可能な仕 樣を第 5 表に示した . 低高度では $\chi$ と $\alpha$ はともに小さく， 逆に $\eta_{\mathrm{t}}$ は大きいが, 高度が上がるにつれ $\chi$ と $\alpha$ は大きく せねばならず $\eta_{\mathrm{t}}$ は小さくしなければならない . 従って衛星 は縦長となりダクトの幅も広くなる. 衛星の直径を 1 とし 
第 5 表 $\mathrm{ABIE}$ 基本仕樣 $\left(C_{\mathrm{D}}=2, \eta_{\mathrm{u}}=0.8, \eta_{\mathrm{s}}=0.2, \epsilon_{\mathrm{o}}=0.8\right.$, $\beta=0.9-\alpha$, および $\left.\theta=45^{\circ}\right)$

\begin{tabular}{ccccccc}
\hline $\begin{array}{c}\text { 高度 } \\
(\mathrm{km})\end{array}$ & $\alpha$ & $\chi$ & $\eta_{\mathrm{t}}$ & $\begin{array}{c}\text { 放電室密度 }^{\mathrm{a}} \\
\left(\mathrm{m}^{-3}\right)\end{array}$ & $\begin{array}{c}V_{\mathrm{A}} \\
(\mathrm{V})\end{array}$ & $\begin{array}{c}p_{\mathrm{A}} \\
\left(\mathrm{kW} / \mathrm{m}^{2}\right)\end{array}$ \\
\hline 140 & 0.25 & 10.0 & 0.4 & $3.28^{+18}$ & 931.0 & 9.31 \\
160 & 0.30 & 10.0 & 0.2 & $2.09^{+18}$ & 883.9 & 3.50 \\
180 & 0.40 & 10.0 & 0.1 & $1.67^{+18}$ & 992.4 & 1.84 \\
190 & 0.40 & 15.0 & 0.1 & $1.44^{+18}$ & 972.4 & 1.35 \\
200 & 0.40 & 20.0 & 0.1 & $1.21^{+18}$ & 953.1 & 1.01 \\
\hline a $3.28^{+18}$ という表記は $3.28 \times 10^{+18}$ の意味. \\
\multicolumn{7}{c}{}
\end{tabular}

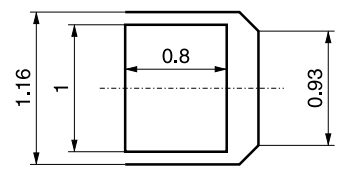

a) 高度 $140 \mathrm{~km}$

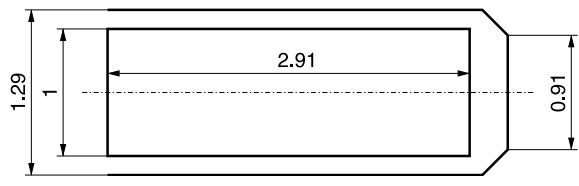

b) 高度 $200 \mathrm{~km}$

第10図 ABIE 形状イメージ

た場合の高度 $140 \mathrm{~km}, 200 \mathrm{~km}$ の ABIE の形状イメージ を第 10 图に示す.高度 $140 \mathrm{~km}$ では $\chi=5$ も可能である が , 衛星がいたずらに小さくなってしまうことから $\chi=10$ を選択している。

最後に ABIE の加速電力について検討を行う . 衛星が太 陽同期軌道を採用すると，太陽光を受けることのできる衛 星の投影面積はおよ光 $2 R_{2} \chi\left(R_{2}-R_{1}\right)$ で与えられる.太 陽電池の効率を 0.2 とおくと, 衛星側面に取り付けられた 太陽電池から供給される総電力は $0.4 P_{\mathrm{s}} \chi R_{2}\left(R_{2}-R_{1}\right)$ と なり，必要な加速電力 $\left(=\pi R_{2}^{2} p_{\mathrm{A}}\right)$ に対する比を $\zeta$ で定義 すると $\zeta=175 \chi(1-\sqrt{1-\alpha}) / p_{\mathrm{A}}$ となる.第 5 表を用い てらを計算すると，高度 $200,190,180,160,140 \mathrm{~km}$ に おいて弚れ光れ $\zeta=0.78,0.44,0.21,0.082,0.025$ となり， すべて 1 より小さい . このことから , 加速に必要な電力は 側壁の太陽電池だけでは供給できず, 別途太陽電池パドル が必要となることがわかる . また高度が低下するにつれて $\zeta$ は急激に低下することから，低軌道では衛星規模と比較し てかなり大きな太陽電池パドルが必要となることがわかる 例えば高度 $180 \mathrm{~km}$ では衛星投影面積の $1 / 0.21-1=3.8$ 倍のパドルが必要となる .

第 1 図に示すようにパドル面は流れに平行に配置される ため, 迎角 $0^{\circ}$ の場合はパドル面積の増加に比例して大気 抗力が増大することはないが, 迎角がある場合はパドル面 積に比例した誘導抵抗が発生することになり，式 (4)の近 似が正確でなくなる . また , 大きな電力器機が必要となり, 重量・構造・制御の問題も発生すると予想される . 今回の
解析では衛星の制御方法や電力に関する検討不充分である ため，これ以上の議論を行うことができない，今後，低軌 道での成立性については, 電力・構造・制御の問題も含め て，より詳細な検討を行う必要がある。

\section{5. ま と め}

空気吸込式イオンエンジン (ABIE) の実現性を検討する ために, 空気力学的な観点から基礎条件を整理し, DSMC 法による空気取込過程の数值解析を行って空気取込性能を 評価した . 圧縮比は雰囲気ガス組成に依存するものの高度に 対する感度は低く, ダクト縦横比が 10 の場合, 高度 140〜 $210 \mathrm{~km}$ では 174〜180 程度であった . 圧縮比はダクト縦横 比, 壁面温度, 壁面の熱適合係数, スクリーングリッド透 過率に依存することがわかり，この関係を評価式で表した .

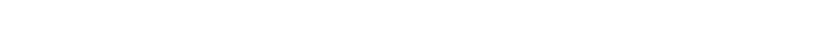
急激に低下することがわかった .この特性角は ABIE の失 速角に相当する。

以上の結果を用いて ABIE の成立性を議論した結果, 空 気力学的な観点からは ABIE は高度 140〜200 km で実現 可能であると予想された . しかし高度 $180 \mathrm{~km}$ 以下では必 要電力か増加し, 構造・制御・電力という他の制約条件が 重要となる可能性が示唆され, 今後の検討課題となった .

\section{参 考 文 献}

1) Nishiyama, K.: Air Breathing Ion Engine Concept, Proc. of 54th International Astronautical Congress, IAC-03-S4-02, Bremen, Germany, 2003.

2) Nishiyama, K.: Air Breathing Ion Engine, Proc. of 24th International Symposium on Space Technology and Science, ISTS-2004-o-3-05v, Miyazaki, Japan, 2004.

3) 宇宙科学研究所 : M-V-5/MUSES-C 飛翔害験計画書, SES-TD02-006, 宇宙科学研究所 SES データセンター, 2003.

4) Drinkwater, M. R., Floberghagen, R., Haagmans, R., Muzi, D. and Popescu, A.: GOCE: ESA's First Earth Explorer Core Mission, Earth Gravity Field from Space-From Sensors to Earth Sciences, Beutler, G. B., Drinkwater, M. R., Rummel, R. and von Steiger, R., eds., Space Sciences Series of ISSI, Vol. 18, Kluwer Academic Publishers, London, 2003, pp. 419-432.

5) 藤田和央, 西山和孝: 空気取込み式イオンエンジンの空気取込み 性能の数値解析, 日本流体力学会年会 2003 講演論文集, 論文番 号 $\mathrm{C}-325,2004$

6) 藤田和央, 西山和孝 : エアーブリージングイオンエンジンの空気 取込性能評価, 日本機械学会流体工学部門講演会論文集, 論文番 号 703,2003, p. 95.

7) Hedin, A. E.: MSIS-86 Thermospheric Model, J. Geophys. Res., 92 (1987), pp. 4649-4662.

8) 上村邦夫, 佐賀達男, 松谷壽信: 宇宙用単結晶シリコン太陽電池, シャープ技報，70 号，1998, pp. 59-64.

9) Fujita, K., Inatani, Y. and Hiraki, K.: Assessment of Dynamic Stability of Blunt-Body Capsules in Hypersonic Rarefied Regime, J. Spacecraft Rockets (in press).

10) Fujita, K., Inatani, Y. and Hiraki, K.: Assessment of Dynamic Stability of MUSES-C Capsule in Hypersonic Rarefied Regime, AIAA Paper 2003-3893, 36th IAA Thermophysics Conference, 2003.

11) Bird, G. A.: Molecular Gas Dynamics and the Direct Simulation of Gas Flows, Clarendon Press, Oxford, 1994. 